Article

\title{
Performance Degradation Analysis of c-Si PV Modules Mounted on a Concrete Slab under Hot-Humid Conditions Using Electroluminescence Scanning Technique for Potential Utilization in Future Solar Roadways
}

\author{
Firoz Khan ${ }^{1}$ and Jae Hyun Kim ${ }^{2, *}$ \\ 1 Center of Research Excellence in Renewable Energy (CORERE), King Fahd University of Petroleum \& \\ Minerals (KFUPM), Dhahran 31261, Saudi Arabia; firoz.khan@kfupm.edu.sa \\ 2 Energy Convergence Research Group, Daegu Gyeongbuk Institute of Science \& Technology (DGIST), 333, \\ Techno Jungang-Daero, Hyeonpung-Myeon, Dalseong-Gun, Daegu 42988, Korea \\ * Correspondence: jaehyun@dgist.ac.kr; Tel.: +82-53-7853610; Fax: +82-53-7853439
}

Received: 11 November 2019; Accepted: 3 December 2019; Published: 5 December 2019

check for updates

\begin{abstract}
The stability of the photovoltaic (PV) modules is critical when deployed in a non-ideal environment. Among the different factors, temperature and humidity are the two major factors affecting PV stability, making them significant causes of its degradation in terms of optoelectric and materials properties. Nowadays, with the increase in PV installation (here, we are only taking account of c-Si-based PV modules) to generate green electricity, effective space utilization is an important issue. Recently, people have been considering deploying PV modules on the road to utilize the space available on highways (roadways). This raises several new issues in the deployment of PV modules. However, issues related to temperature and humidity retain the same importance. Normally, these stability tests are performed in a damp-heat (DH) stress-testing chamber in an accelerated condition at $85^{\circ} \mathrm{C}$ and $85 \%$ relative humidity (RH). In this work, c-Si PV modules were fixed over a concrete slab to prepare a PV interacted block, which can be used to build concrete-based roads. The performance of this PV on the concrete slab was tested in a DH stress-testing chamber in an accelerated condition at $85{ }^{\circ} \mathrm{C}$ and $85 \% \mathrm{RH}$ for $4000 \mathrm{~h}$. For the comparison, a PV module without concrete was also evaluated. The degradation of the PV modules was characterized using the electroluminescence scanning technique. After $2500 \mathrm{~h}$ of exposure to the $\mathrm{DH}$ conditions, the performance retention of the PV modules mounted on the concrete was $93.2 \%$, which was nearly $5 \%$ higher than the module without the concrete slab.
\end{abstract}

Keywords: renewable energy; PV module; solar roadways; PV degradation; electroluminescence scanning; PV cell parameters

\section{Introduction}

Crystalline silicon (c-Si) is dominating the PV market, because of its superior stability and performance, both of which affect the financial viability of solar PV installations. Normally, the PV modules pass through the stability certification under different simulated environmental conditions before commercialization. These procedures include damp-heat (DH), thermal cycling (TC), UV exposure, mechanical load, etc., as well as various other aging mechanisms [1]. However, for a highly specific application environment, this stability certification may not be sufficient to necessitate PV installation. Thus, it required specific study of the PV modules performances under that particular environment. 
Again, since PV based power plants occupy considerable land space, several countries are considering utilizing the free space of roadways. This would mean the space could be used for transportation and power generation at the same time. However, degradation and reliability are key factors in the implementation of this plan. Among the various factors affecting the stability of the PV modules, temperature and damp are more present than ever.

Common c-Si PV modules available on the market are guaranteed to operate for $\sim 25$ years and still provide $80 \%$ of initial power after this period [2]. To meet this standard, PV modules have to survive 25 years of outdoor exposure under real environmental conditions. Since waiting for 25 years to obtain the data is unfeasible, several indoor characterization techniques have been recommended by the International Electrotechnical Commission (IEC) 61215 [2,3]. These procedures, including DH, TC, UV exposure, mechanical strength, etc., can be used to explore various aging mechanisms [1-3]. There are several reports available in the literature that deal with DH testing for estimating the reliability and lifetime of PV modules [1,4-8]. Regrettably, most of these tests simply determine whether the PV modules passed or failed the test. However, some of the papers deal with estimating the lifetime of the modules. For example, Hacke et al. [9] used DH testing, in situ dark current-voltage $(I-V)$ measurement (biased at $-600 \mathrm{~V}$ ) and ex-situ illuminated $I-V$ measurement at $100 \mathrm{~mW} / \mathrm{cm}^{2}\left(25^{\circ} \mathrm{C}\right.$ ) to estimate the degradation rate and predict lifetime. Zhu et al. [1] used various environmental conditions for the DH testing of three types of PV modules (with different types of back sheets). They [1] derived humidity dose from humidity, temperature, and time $\left(1\right.$ dose $\approx 1430 \mathrm{~h} \mathrm{DH}$ stress at $85^{\circ} \mathrm{C}, 85 \%$ relative humidity, RH), and this data was then used to extract the power degradation, along with some of the solar cell parameters. Other research groups $[1,2,10]$ have studied the degradation of some PV cell parameters (photogenerated current $I_{p h}$, shunt resistance $R_{s h}$, series resistance $R_{s}$, diode ideality factor $n$ and reverse saturation current $I_{0}$ ) under DH stress.

In this work, c-Si PV modules were mounted on the concrete slab, which can be used to study the effect of high temperature and high humidity on the contraction of roadways. As no similar study is available, the power degradation of PV mounted concrete slabs was monitored in a simulated environment $\left(85^{\circ} \mathrm{C}\right.$ and $\left.85 \% \mathrm{RH}\right)$ in an accelerated condition for $4000 \mathrm{~h}$, and data were collected at different time intervals. Degradation of the performance parameters such as short circuit current $I_{s c}$, open-circuit voltage $V_{o c}$, fill factor $F F$ and efficiency $\eta$ were compared with the unmounted PV module. Five analytical PV cell parameters were used to conduct a loss analysis. The degradation of the PV modules was also characterized using the electroluminescence (EL) scanning technique.

\section{Experimental Section}

Monocrystalline PV modules ( $20 \mathrm{~W})$ were used for this study. The rigid modules included 36 cells, with an $\mathrm{Al}$ frame (module area $=1540 \mathrm{~cm}^{2}$, cell area $=31.2 \mathrm{~cm}^{2}$ ). DH stress was conducted at a temperature of $85^{\circ} \mathrm{C}$ and a relative humidity of $85 \%$ for a DH stress cycle of $250 \mathrm{~h}$ (Figure 1). The DH test was conducted using an environmental chamber (Model: DS-323MHPS-153, M/s. DIMOSTECH, Incheon, Korea). Solar PV modules without concrete (3 modules), where the backside of the module was exposed to the environment, were used as a reference. However, the backside of the PV modules was covered with a concrete-filled metallic isolation box (4 modules, double-wall construction, with an insulating material filling the gap between the walls). After fitting the PV module with the isolation box, the gap between the edges of the module and the box was sealed with Kapton (polyimide) tape. The tape protected the backside of the module from moisture and heat (Figure 2). After each cycle $(250 \mathrm{~h})$, the PV modules were visually inspected using optical photographs of the front and rear surfaces. The EL scanning technique was used to obtain EL images using the EL system (Model: TE-2000, M/s. TNETECH, Gyeonggi-do, Korea) by applying a short circuit current. 


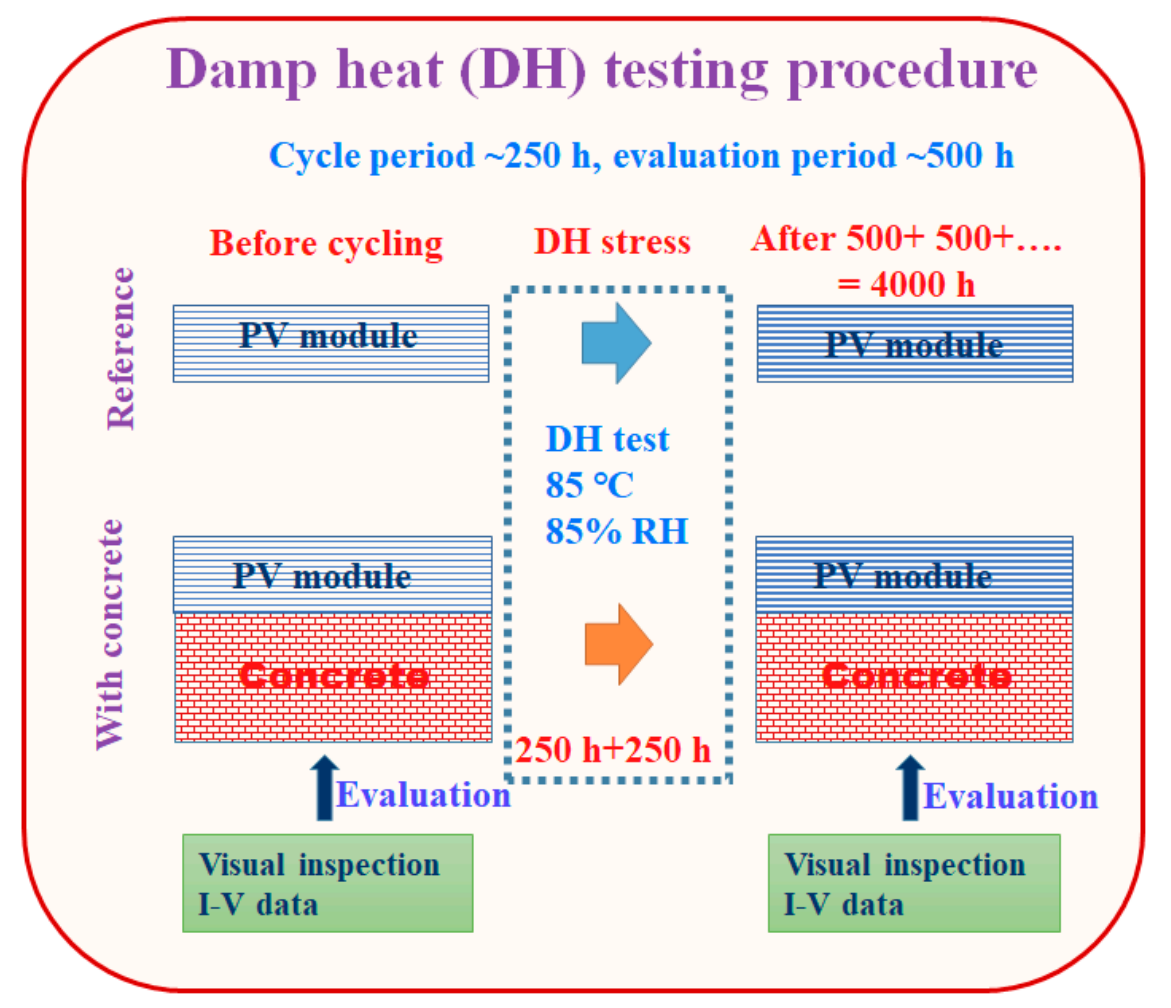

Figure 1. Schematic for the procedure used for Damp-Heat (DH) stress test.

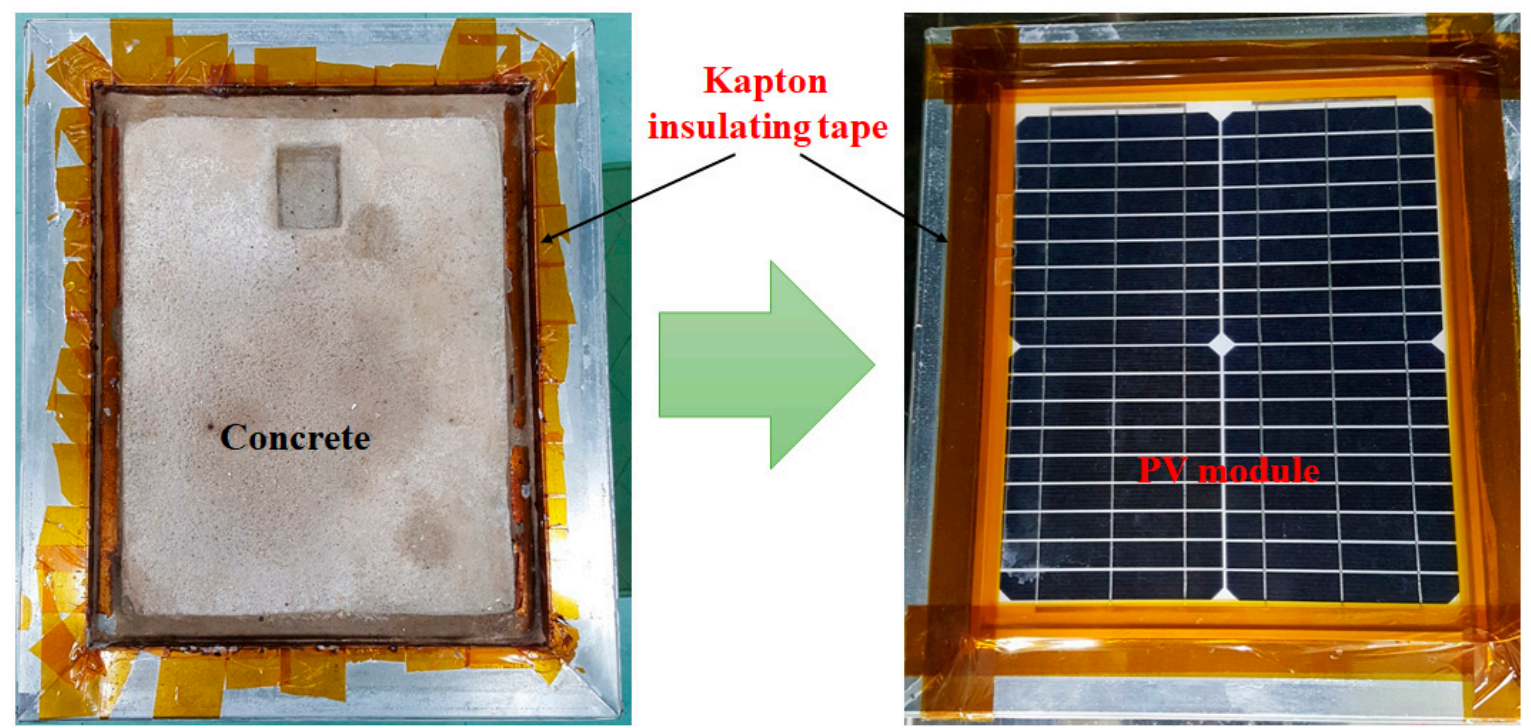

Figure 2. Optical image of (left) metallic isolation box with concrete (concrete slab) and (right) photovoltaic (PV) module mounted on concrete slab.

Illuminated $I-V$ characterization was conducted after each $500 \mathrm{~h}$ of $\mathrm{DH}$ stress. The illuminated $I-V$ characteristics were obtained with a Keithley 2420 System SourceMeter using a solar simulator M/s Spire (Model: SPI-SUN SIMULATOR 4600SLP, The Hague, Netherlands) at $25^{\circ} \mathrm{C}$ under $100 \mathrm{~mW} / \mathrm{cm}^{2}$ illumination intensity of a simulated AM 1.5 Global solar spectrum. The intensity of illumination was measured using a reference silicon solar cell obtained from PV Measurements, Washington, DC, USA. 


\section{Results and Discussion}

\subsection{Performance Parameters Analysis}

Four PV modules were used with the concrete slab, with three PV modules as references. Similar degradation was observed in each group. Here, one PV module in each group has been analyzed in detail. Moisture normally diffused into solar modules through their breathable back sheets or ethylene-vinyl acetate (EVA) sheets. In solar roadways, the top layer of the PV modules will be high-grade glass, so the backside of the PV module should be protected by moisture absorbent materials. Concretes will be a cheaper option to provide both mechanical strength and protection against the moisture or humidity, and even, to some extent, short flooding with water. Here, the PV modules were fixed on a concrete slab using the isolation box and Kapton insulating tape, and the results were promising. Compared to a reference PV module (without a concrete slab on the back), normalized values of the output power were improved when concrete was used. $I-V$ curves of PV modules monitored without (reference PV module) and with concrete for different DH durations are shown in Figure 3a,b, respectively. Corresponding power-voltage $(P-V)$ curves are shown in Figure 4. Performance parameters that were extracted from the $I-V$ data are presented in Figure 5.
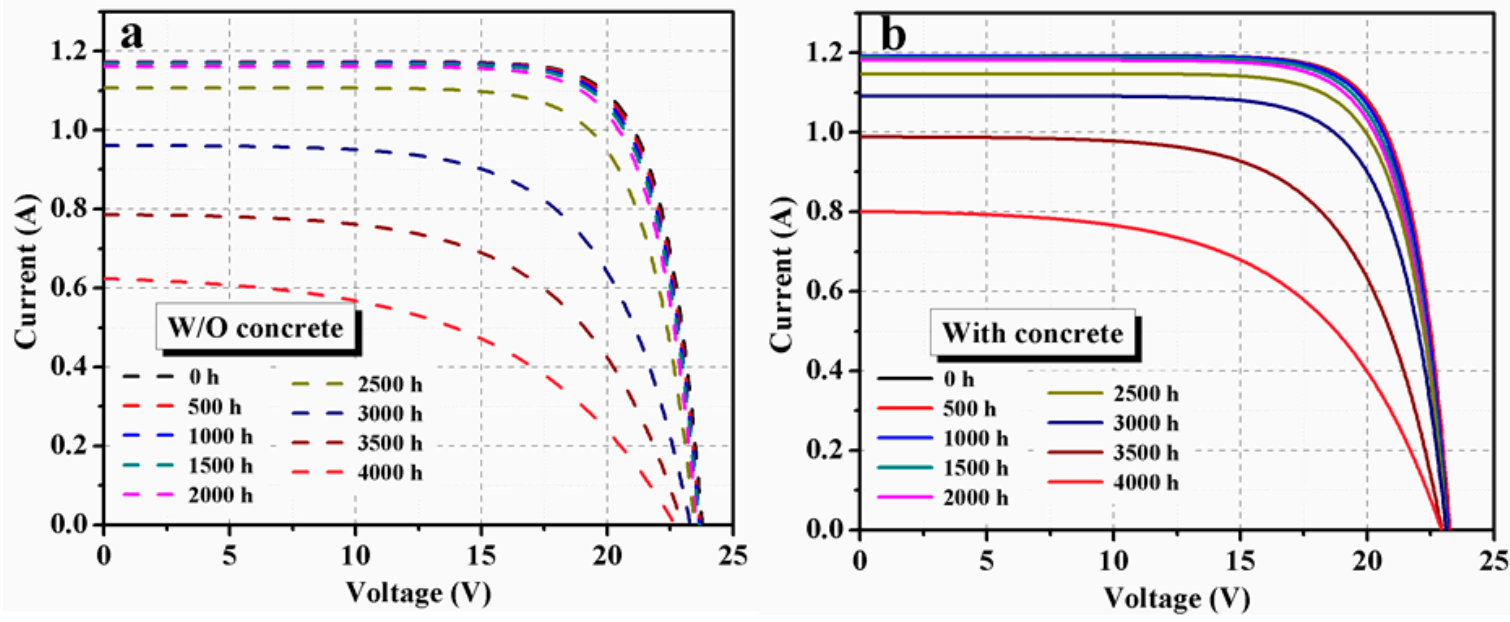

Figure 3. Illuminated $I-V$ curves for various DH stress duration of PV module (a) without concrete, and (b) with concrete.
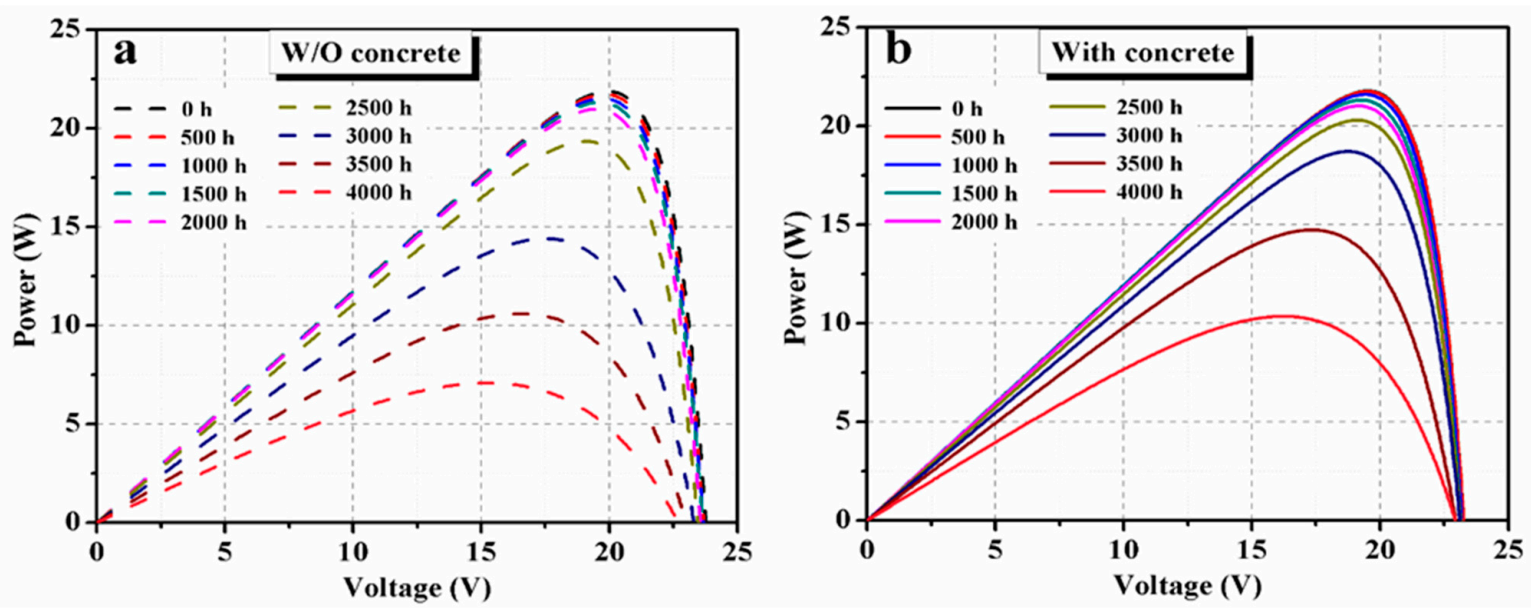

Figure 4. Illuminated $P-V$ curves for various $\mathrm{DH}$ stress duration of $\mathrm{PV}$ module (a) without concrete, and (b) with concrete. 

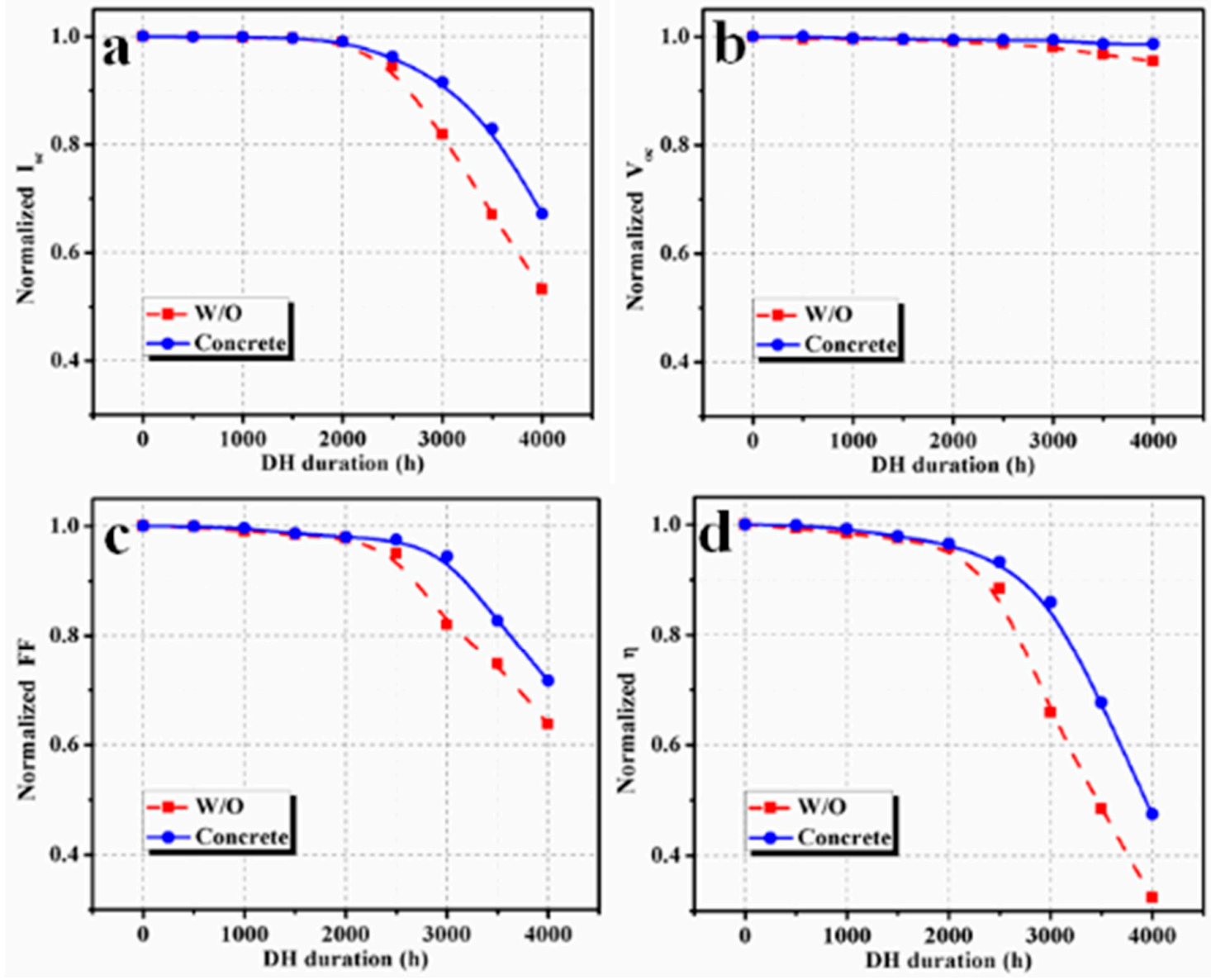

Figure 5. The variation of (a) short circuit current, (b) open-circuit voltage, (c) fill factor and (d) conversion efficiency with DH stress duration.

There was no significant change in $V_{o c}$ in either PV module until $1500 \mathrm{~h}$ in a DH chamber. However, as the duration increased further, the $V_{o c}$ value of the reference module started to degrade considerably compared to the $V_{o c}$ value of the PV module with concrete. After $4000 \mathrm{~h}$, the obtained degradation in $V_{o c}$ was $4.5 \%$ and $1.4 \%$, respectively, for reference and concrete-PV modules. Compared to the concrete-PV module, both $I_{s c}$ and $F F$ were reduced faster up to $2000 \mathrm{~h}$ in the reference PV module. The normalized value of $\eta$ of the PV module with concrete was reduced to $96.5 \%, 85.9 \%$ and $47.5 \%$ for the DH duration of 2000, 3000 and $4000 \mathrm{~h}$, respectively. On the other hand, the $\eta$ value of the reference PV module was reduced to $95.9 \%, 65.9 \%$ and $32.4 \%$ of its initial value for DH duration of 2000, 3000 and $4000 \mathrm{~h}$, respectively.

EL results demonstrate that there was no defect in both the PV modules before the DH stress test (Figure 6). The $I_{s c}$ degradation of both PV modules was very slow for up to $2000 \mathrm{~h}$ of DH exposure. However, the degradation of the rate of $I_{s c}$ of PV module with concrete was slightly lower than the reference PV module in this duration. Figure 7 shows the EL images of the reference PV module and PV modules with concrete after a DH stress of $2000 \mathrm{~h}$. Defective regions are indicated by the red dotted/dashed rectangles/circle (Figure 7a). A lower number of defects was found in the PV modules with concrete (Figure $7 \mathrm{~b}$ ), which revealed that the impact of DH stress on the PV module with concrete was smaller than that of the reference module. With a further increase in $\mathrm{DH}$ duration, the $I_{s c}$ degradation rate for the reference PV module was faster than that of the PV module with concrete. After a DH stress of $3000 \mathrm{~h}$, the $I_{s c}$ values were reduced to $81.9 \%$ and $91.5 \%$ of their initial values, respectively, with reference to the PV module and PV module with concrete. The DH stress caused inhomogeneous aging in the PV modules, which reduced the current generation. Hence, $I_{s c}$ was reduced with DH stress [1]. Finally, after $4000 \mathrm{~h}$ in a DH chamber, the $I_{s c}$ values of the reference and 
PV module with concrete were reduced to $53.2 \%$ and $67.2 \%$, respectively. This shows that for 3000 and $4000 \mathrm{~h}$ of $\mathrm{DH}$ exposure, the $I_{S C}$ value was reduced by $9.6 \%$ and $24.0 \%$, respectively, when concrete was used.
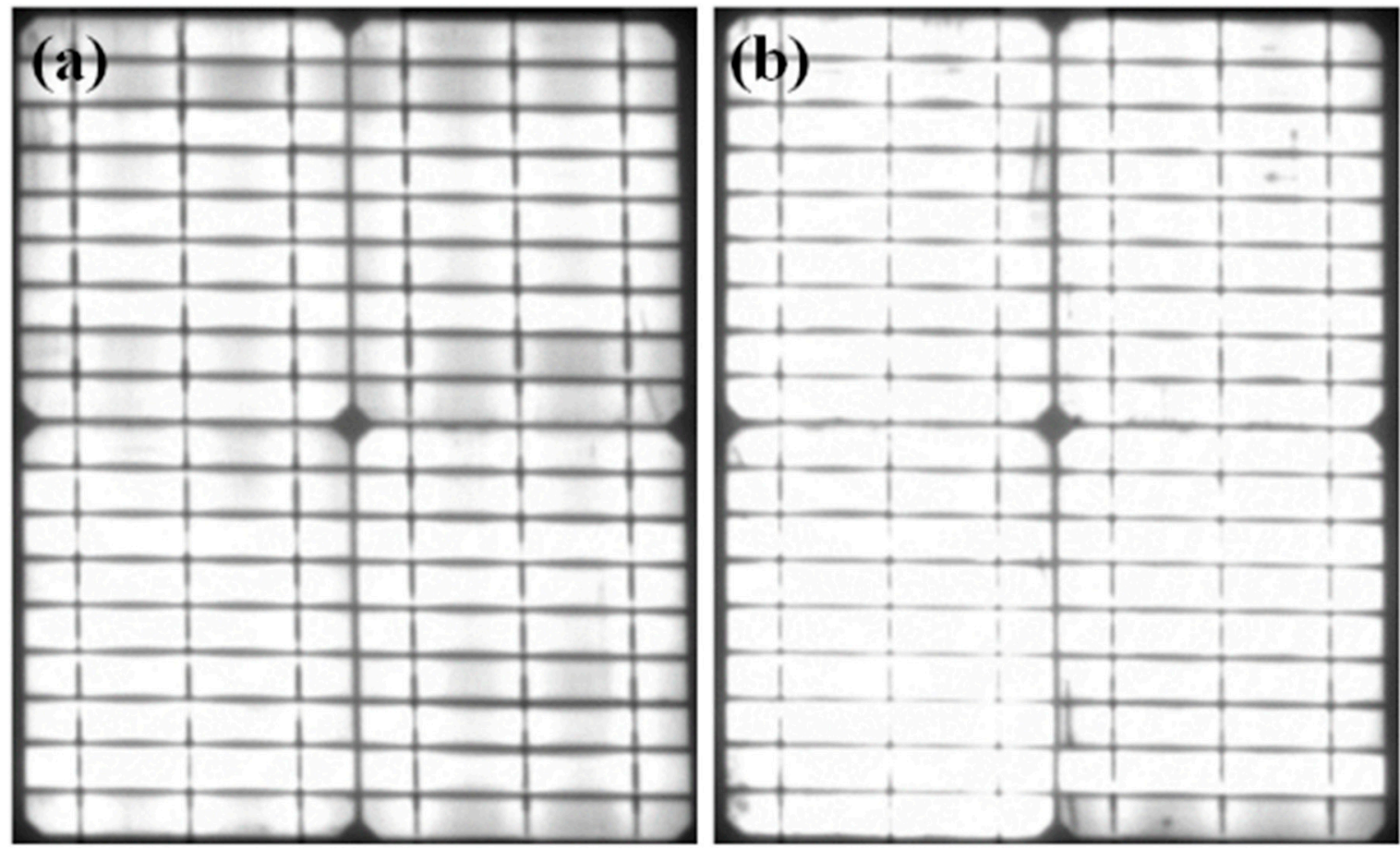

Figure 6. Electroluminescence images of PV modules (a) without concrete, and (b) with concrete before DH stress test.
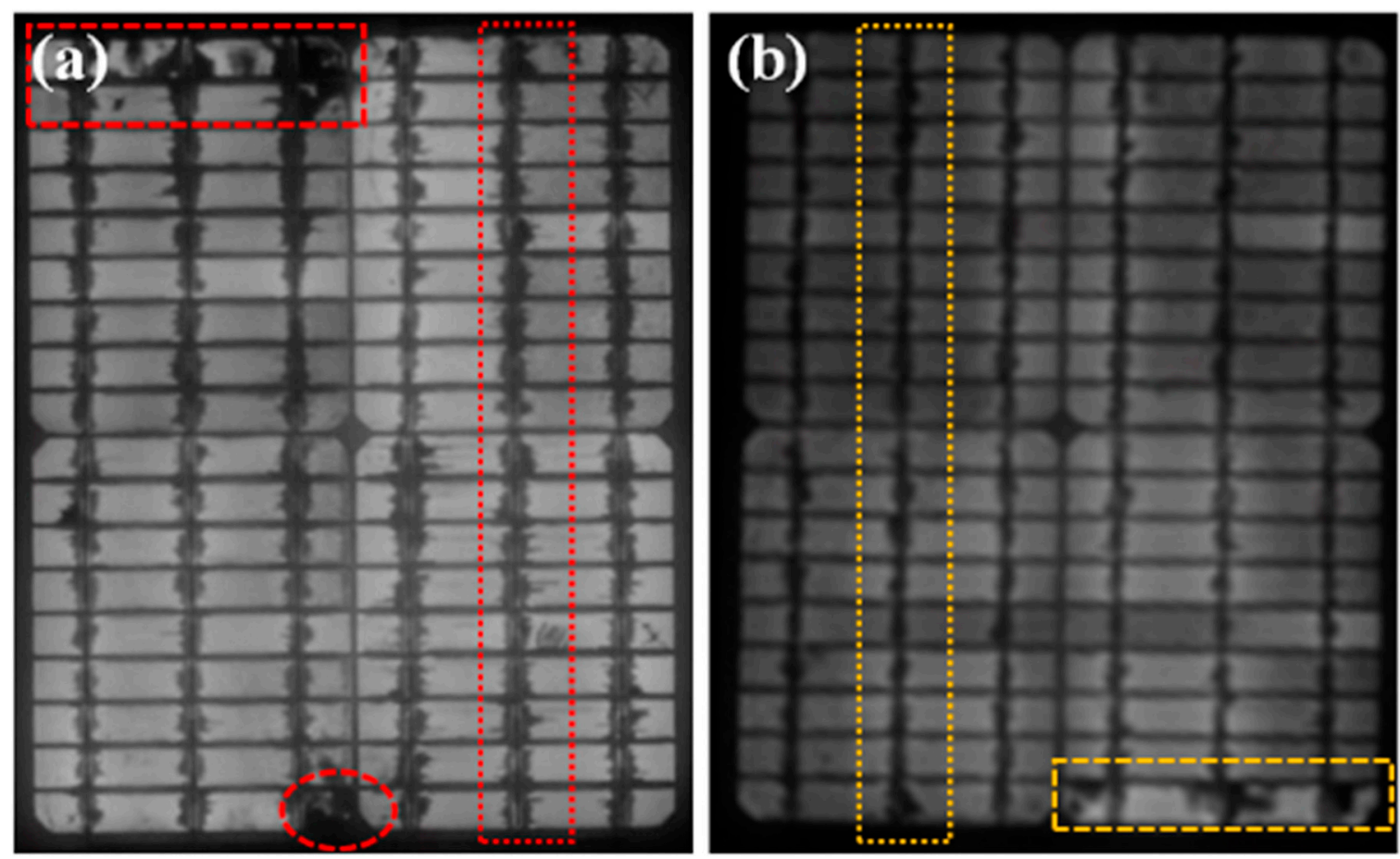

Figure 7. Electroluminescence images of PV modules (a) without concrete, and (b) with concrete after DH stress duration of $2000 \mathrm{~h}$. 
Optical photographs of the backside of the PV modules after DH stress of $2000 \mathrm{~h}$ are shown in Figure 8. There is rust on the metal connection in the junction box (inset of Figure 8a) of reference PV modules. However, no rust is seen in the junction box of the PV module with concrete (inset of Figure $8 b$ ). These results demonstrate that the concrete contained an isolation box protects the backside of PV modules from exposure to moisture.
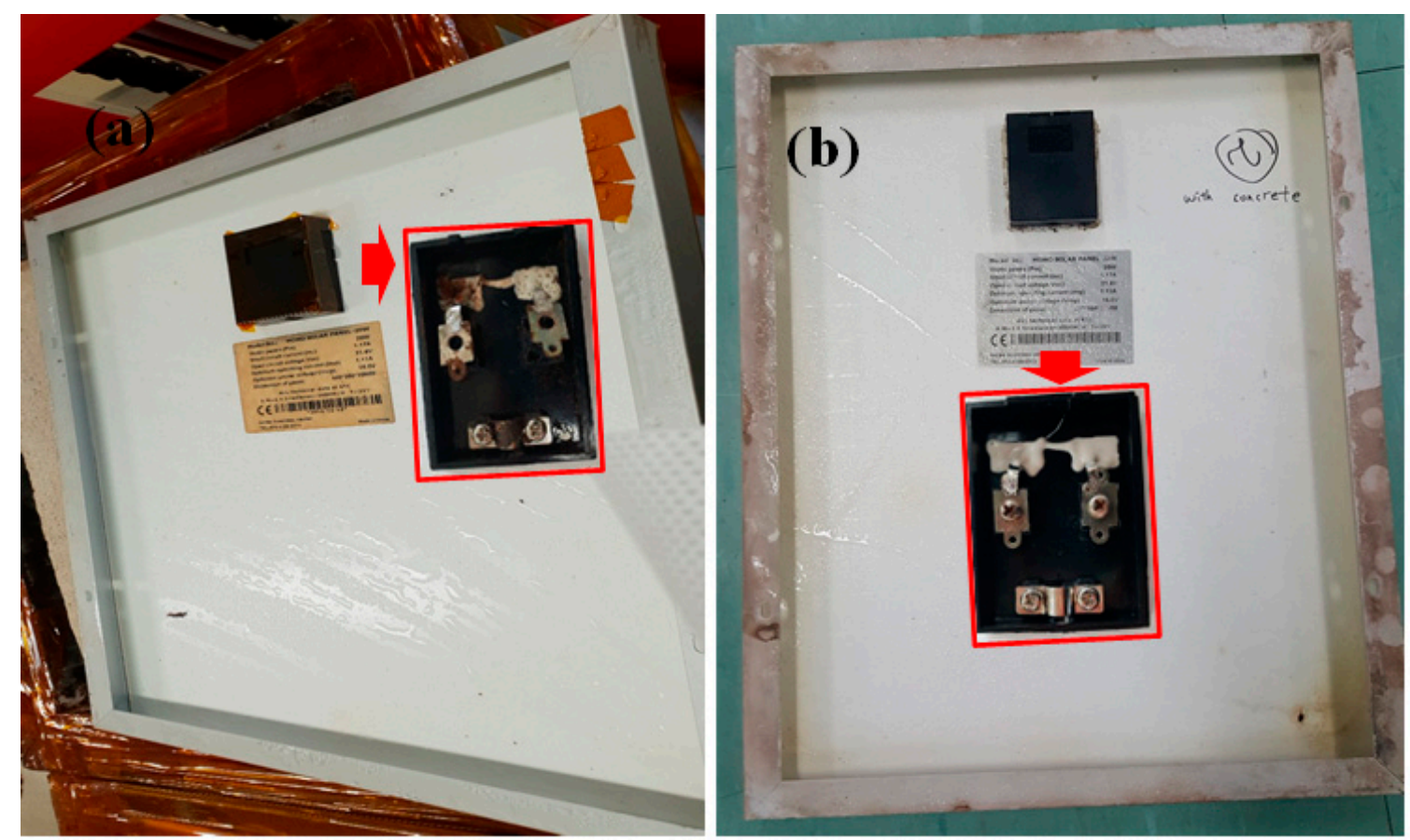

Figure 8. Optical photographs of backside PV modules (a) without concrete, and (b) with concrete after DH stress duration of $2000 \mathrm{~h}$. (Inset optical photographs of junction box and of corresponding PV modules).

Overall, the output power degradation rate in the PV modules with concrete was lower than the reference module. The degradation of maximum power $\left(P_{m}\right)$ is shown in Figure $9 \mathrm{a}$. The corresponding current $\left(I_{m}\right)$ and voltage $\left(V_{m}\right)$ degradation at the maximum power point are shown in Figs. $9 \mathrm{~b}$ and c, respectively. The degradation rate of $P_{m}$ in both PV modules was slow until $2000 \mathrm{~h}$ of exposure. Normalized $P_{m}$ values of the PV-concrete module obtained for DH durations of 2000, 2500, 3000, 3500 and $4000 \mathrm{~h}$ were $96.5 \%, 93.2 \%, 85.9 \%, 67.6 \%$ and $47.5 \%$, respectively. The corresponding normalized $P_{m}$ values for the reference PV module are $95.9 \%, 88.4 \%, 65.9 \%, 48.5 \%$ and $32.4 \%$ for DH duration of 2000 , 2500, 3000, 3500 and $4000 \mathrm{~h}$, respectively. A similar $P_{m}$ degradation in the reference PV module over DH duration was observed experimentally and by modeling on previous reports [1,2]. Zhu et al. [1] observed that the degradation rate of a PV module can be reduced using an aluminum moisture barrier with a back EVA sheet.

It can be seen from Figure 9 that the degradation of $I_{m}$ had a greater impact on the degradation of $P_{m}$ than $V_{m}$ because DH stress reduces the current generation. For a DH duration of $3000 \mathrm{~h}$, the normalized $I_{m}$ values of reference PV module and PV modules with concrete reduced to $75.2 \%$ and $89.6 \%$ of their initial values, respectively. Relative enhancement in the performance parameters of the PV module with concrete, concerning the reference PV module, is shown in Figure 10. A significant relative improvement of more than $10 \%$ was found for $P_{m}$ for $\mathrm{DH}$ duration beyond $2500 \mathrm{~h}$. This confirms that using concrete reduces the impact of the temperature and humidity on the PV modules, which eventually enhances the performance lifetime of the PV modules. 

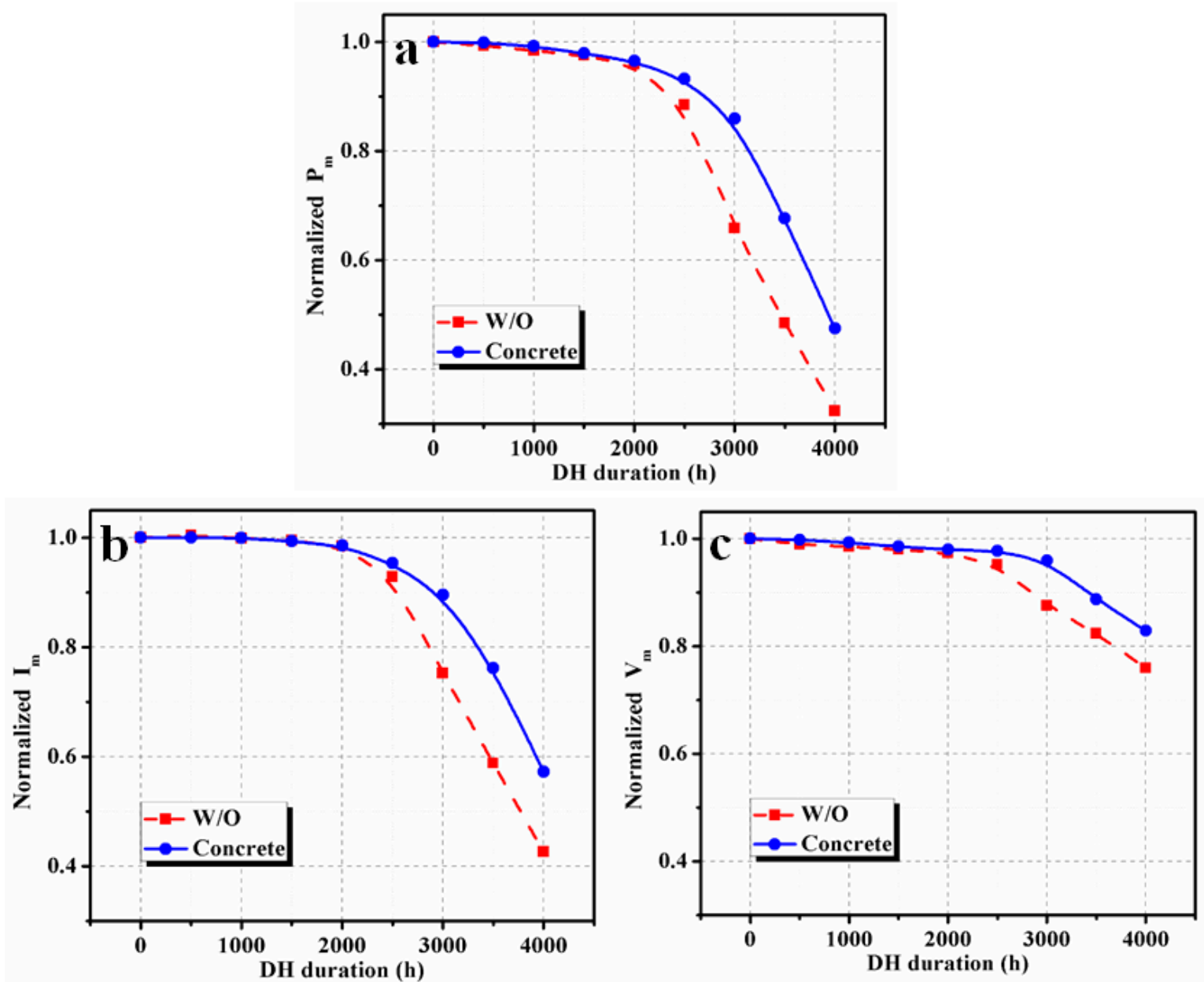

Figure 9. The dependency of (a) output power, (b) current, and (c) voltage at maximum power point on DH stress duration.

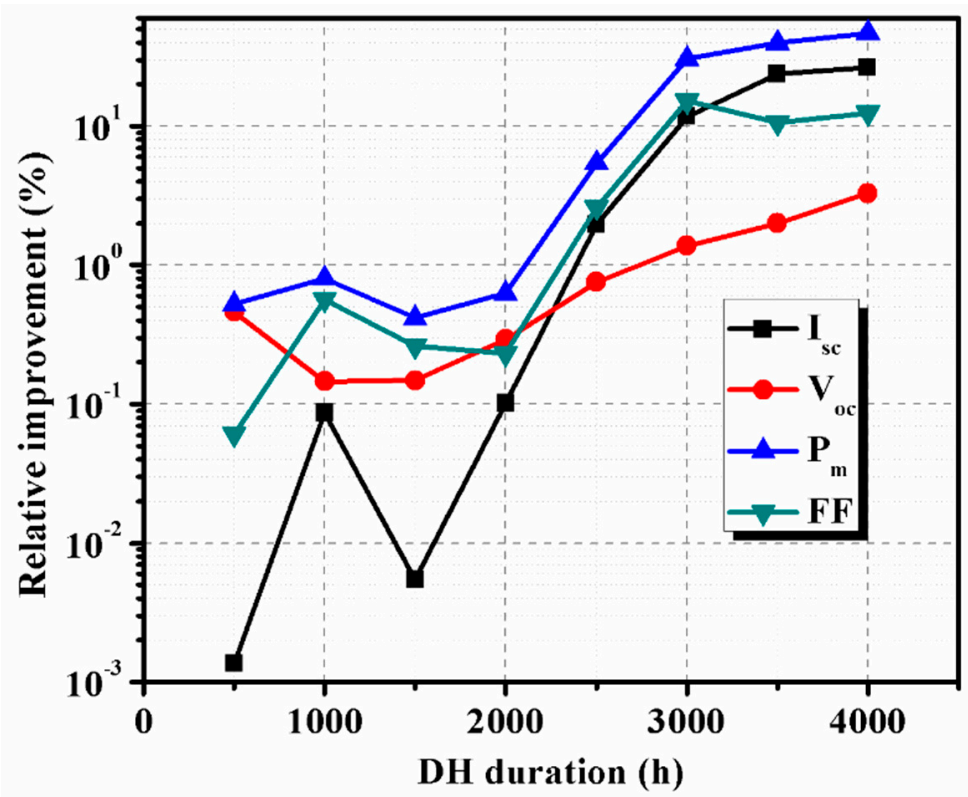

Figure 10. The relative improvement of performance parameters of the PV module with concrete, concerning parameters of PV module without concrete. 


\subsection{PV Cell Parameters Analysis}

Degradation of the performance parameters can also be explained using the five PV cell parameters. PV cell parameters of the PV modules are compared in Figure 11. Steady-state $I-V$ characteristic of p-n junction solar cells, based on a one-diode model [11,12] operating in the first quadrant, is described in [13] as
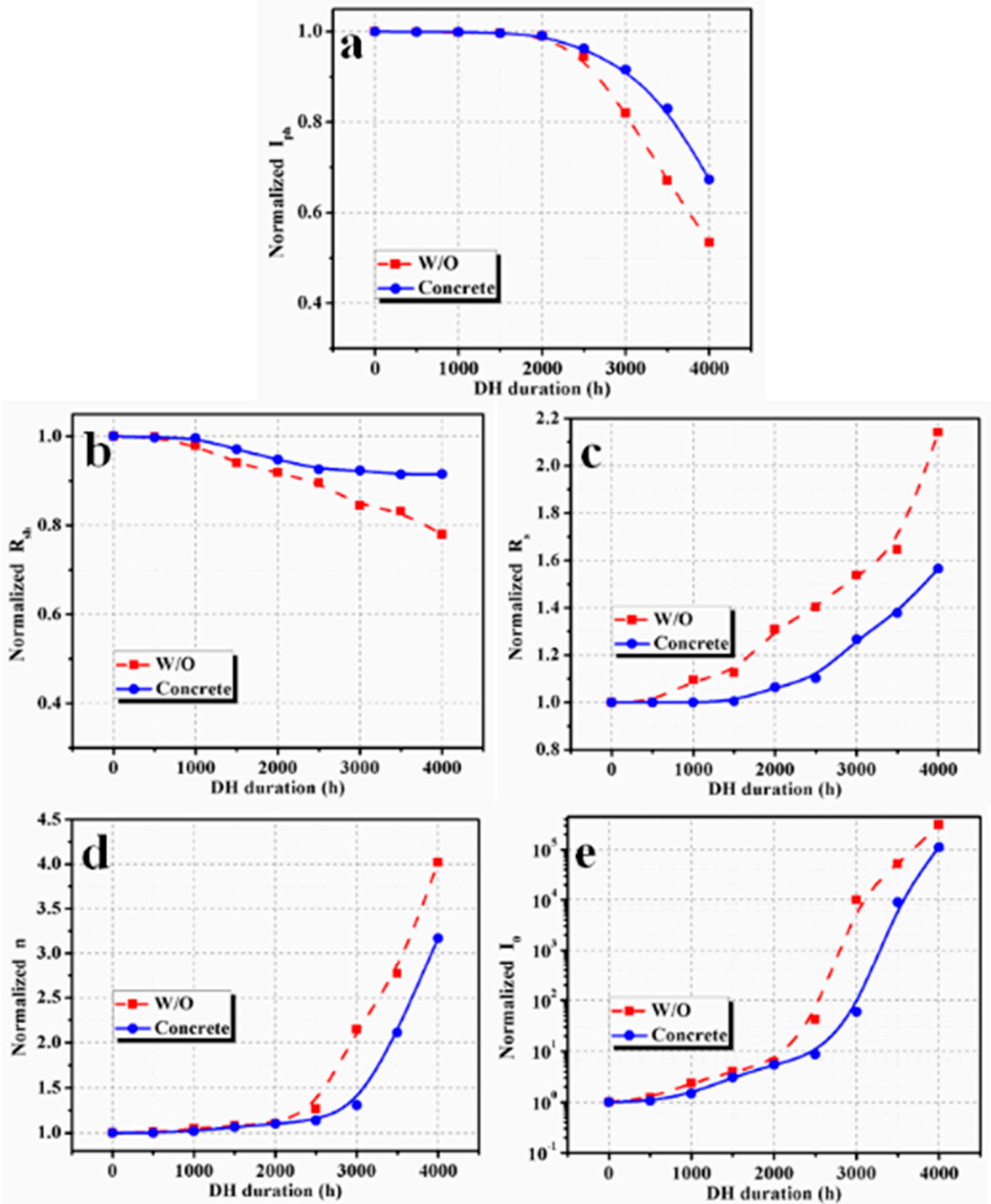

Figure 11. Variation of (a) photo-generated current, (b) shunt resistance, (c) series resistance, (d) diode ideality factor, and (e) reverse saturation current. 


$$
I=I_{p h}-I_{0}\left[e^{\left(\frac{V+I R_{s}}{n V_{T}}\right)}-1\right]-\left(\frac{V+I R_{s}}{R_{s h}}\right)
$$

The analytical method used in this case $[13,14]$ is based on a single exponential model, which can be used to determine the PV cell parameters at operating temperature $T$ under given illumination conditions. This method uses a single $I-V$ characteristic curve to determine the five analytical PV cell parameters. The following equations are used to extract the values of $I_{p h}, R_{s h}, R_{s}, n$, and $I_{0}$, using the values of $I_{s c}, V_{o c}, R_{s c}, R_{o c}, I_{m}$, and $V_{m}$.

$$
\begin{gathered}
I_{p h}=I_{s c}\left(1+\frac{R_{s}}{R_{s h}}\right)+I_{0}\left[e^{\left(\frac{I_{s c} R_{s}}{n V_{T}}\right)}-1\right] \\
R_{s h}=R_{s c} \\
n=\frac{\left(V_{m} \mp R_{o c} I_{m}-V_{o c}\right)}{R_{s}=R_{o c}-\frac{n V_{T}}{I_{0}} e^{-\frac{V_{o c}}{n V_{T}}}} \\
V_{T}\left\{\ln \left(I_{s c}-\frac{V_{m}}{R_{s c}}-I_{m}\right)-\ln \left(I_{s c}-\frac{V_{o c}}{R_{s c}}\right)+\left(\frac{I_{m}}{I_{s c}-\frac{V_{o c}}{R_{s c}}}\right)\right\} \\
I_{0}=\left(I_{s c}-\frac{V_{o c}}{R_{s c}}\right) e^{-\frac{V_{o c}}{n V_{T}}}
\end{gathered}
$$

Here, $R_{s c}=(\mathrm{d} \mathrm{d} / \mathrm{d} V)^{-1}$ at short circuit conditions $\left(V=0, I=I_{s c}\right), R_{o c}=(\mathrm{d} I / \mathrm{d} V)^{-1}$ at open circuit conditions $\left(V=V_{o c}, \mathrm{I}=0\right)$, and $V_{T}=\mathrm{k} T / \mathrm{q}$ ( $\mathrm{k}$ being the Boltzmann's constant, and q the elementary electronic charge).

A similar variation in $I_{p h}$, as observed in $I_{s c}$, is obtained with DH duration, confirming that the DH stress has a decisive effect on current generation. In most cases, the $I_{p h}$ linearly depends on $I_{s c}$ [14]. The value of $R_{s h}$ in the PV module with concrete is nearly constant up to a DH duration of $1000 \mathrm{~h}$ and reduces to $92.6 \%$ after $2500 \mathrm{~h}$ of exposure. With a further increase in DH duration to $4000 \mathrm{~h}, R_{s h}$ is reduced to $91.5 \%$. However, the value of $R_{s h}$ in the reference module starts a gradual reduction from $500 \mathrm{~h}$ and then decreases to $89.6 \%$ and $77.9 \%$ of the initial value at $2500 \mathrm{~h}$ and $4000 \mathrm{~h}$, respectively. Typically, $R_{s h}$ is a parallel highly-conductive path within the PV cell due to local imperfection regions, which contain a large number of traps [15]. This occurs because the traps sink the majority charge-carriers or the light-generated minority charge-carriers [16]. More traps are generated with an increasing DH exposure [17], which results in local inhomogeneity in the traps and enhances the non-uniform current flow [18], as well as the leakage current through the p-n junction or from the edge [15]. These traps are more dynamic under low illumination conditions [19]. A low value of $R_{s h}$ has a detrimental effect on $V_{o c}$ and $F F$, and thereby module performance, particularly at low intensity [10] or a higher operating temperature [14]. The value of $R_{S}$ exponentially increases with a rise in DH duration. The variation range of $R_{s}$ was found to be lower in the PV module with concrete than the reference module, whereas it increased faster in the reference PV module. $R_{s}$ value of the PV module with concrete increased by $10 \%$ after $2500 \mathrm{~h}$, while it increased by $40 \%$ for the reference PV module. Moreover, after DH stress of $4000 \mathrm{~h}$, the value of $R_{S}$ increased by $56 \%$ and $114 \%$ for PV modules with concrete and reference modules, respectively. The $R_{s}$ value of a PV module is the combined resistance of the PV cell (base and emitter), front/back contacts, the resistance of solder bonds, and the resistance of junction boxes. The DH stress increased defects in the PV material ( $\mathrm{Si}$ ) and deteriorated contact between $\mathrm{Si}$ and metallic contacts. Thus, the overall series resistance was increased. Moreover, the reduction of current generation was also a reason to increase the value of the $R_{S} . R_{S}$ severely shrinks the value of $F F$ of the cell and thus degrades the cell efficiency. Correspondingly, $n$ and $I_{0}$ values also increased with an increase in DH duration. This severely decreased the $F F$ of the 
PV modules and consequently reduced performance [20]. The value of $n$ increased to 3.1 times its initial value for DH duration of $4000 \mathrm{~h}$, while the increment of $n$ value was higher for the reference module (4 times for DH duration of $4000 \mathrm{~h}$ ). $I_{0}$ values increased to 311,645.4 times and 111,654.9 times for the reference module and PV module with concrete, respectively, for DH duration of $4000 \mathrm{~h} . V_{o c}$ and $F F$ values were intensely affected by $n$ and $I_{0}$, where $I_{0}$ had a decisive effect on the $V_{o c}$. The rise in the value of $n$ resulted in a higher $V_{o c}$ value, while the $F F$ was severely reduced with an increase in $n$ value [20]. It can be seen that the degradation in the $V_{o c}$ values are quite low, while the corresponding $\mathrm{n}$ values are enormously affected with the $\mathrm{DH}$ duration. This is accredited to inhomogeneous ageing of the PV cells and the cell mismatch.

The trend in the variation of the PV cell parameters of the reference PV module was similar to the cell parameters of the PV module without a moisture barrier reported by Zhu et al. [1]. However, in their study, the losses were reduced by the insertion of an aluminum moisture barrier on the EVA back sheet. Again, the metallic isolation box with concrete also worked as an effective moisture barrier and reduced the reduction rate of performance. Concrete slabs absorbed some fraction of the moisture, which diffused through the Kapton tape at the edges of the module and thus effected the power degradation rate.

\subsection{Measurement Error Analysis}

The error in the directly measured quantities are under a level of confidence [21,22]. However, errors propagation method is used to determine the errors in the calculated parameters. The error limits of various parameters are listed in Table 1.

Table 1. Error limits of the measured/calculated quantities.

\begin{tabular}{cc}
\hline Parameters & Error (\%) \\
\hline$I_{s c}(\mathrm{~A}), I_{m}(\mathrm{~A}), V_{o c}(\mathrm{~V}), V_{m}(\mathrm{~V})$ & 0.12 \\
$F F$ & 0.21 \\
$P_{m}, \eta$ & 0.56 \\
\hline
\end{tabular}

\section{Conclusions}

IEC standard DH stress testing conditions were used to evaluate the PV module's degradation of the performance parameters on the PV mounted on a concrete slab. PV cell parameters were analyzed to study the loss mechanism. The comparative study showed that using concrete contained in isolation boxes can reduce the rate of performance degradation of the PV module. EL results revealed that fewer defects were created in the PV module with concrete than the reference module without any concrete slab. Normalized $P_{m}$ values of the PV module with concrete obtained for DH durations of 2000, 2500, 3000, 3500 and $4000 \mathrm{~h}$ were $96.5 \%, 93.2 \%, 85.9 \%, 67.6 \%$ and $47.5 \%$, respectively. Corresponding normalized $P_{m}$ values obtained for the reference PV module were $95.9 \%, 88.4 \%, 65.9 \%, 48.5 \%$ and $32.4 \%$ for DH durations of 2000, 2500, 3000, 3500 and $4000 \mathrm{~h}$, respectively. For the DH duration of $4000 \mathrm{~h}$, the values of $n$ increased by 4.0 times and 3.1 times for the reference module and PV module with concrete, respectively. Similarly, the corresponding $I_{0}$ values of the reference and PV module with concrete increased to 311,645.4 times and 111,654.9 times, respectively. From this preliminary study, it is clear that the concrete back layer plays an important part in the protection of the PV modules from the destructive effects of high temperature and humidity. A more in-depth study is required, and modified PV modules will be introduced for viable solar roadways, which is in progress in our laboratory.

Author Contributions: F.K. anticipated the idea and design the experimentations. J.H.K. conducted the experiments. F.K. and J.H.K. examined the results and drafted the paper.

Funding: This research was funded by the Energy Technology Development Program of the Korea Institute of Energy Technology Evaluation and Planning (KETEP, Grant No. 20173010012880), Republic of Korea. 
Acknowledgments: The authors are very thankful to Energy Technology Development Program of the Korea Institute of Energy Technology Evaluation and Planning (KETEP) for providing financial support to conduct this work. The author F.K. gratefully acknowledges the Center of Research Excellence in Renewable Energy (CORERE), Research Institute, King Fahd University of Petroleum \& Minerals (KFUPM), Kingdom of Saudi Arabia.

Conflicts of Interest: The authors declare no conflict of interest.

\section{References}

1. Zhu, J.; Koehl, M.; Hoffmann, S.; Berger, K.A.; Zamini, S.; Bennett, I.; Gerritsen, E.; Malbranche, P.; Pugliatti, P.; Di Stefano, A.; et al. Changes of solar cell parameters during damp-heat exposure. Prog. Photovolt. 2016, 24, 1346-1358. [CrossRef]

2. Braisaz, B.; Duchayne, C.; Iseghem, M.V.; Radouane, K. PV aging model applied to several meteorological conditions. In Proceedings of the 29th European Photovoltaic Solar Energy Conference and Exhibition (EUPVSEC), Amsterdam, The Netherlands, 22-26 September 2014; pp. 2303-2309.

3. Crystalline Silicon Terrestrial Photovoltaic (PV) Modules-Design Qualification and Type Approval; IEC 61215:2005; IEC Central Office: Geneva, Switzerland, April 2005.

4. Wohlgemuth, J.H.; Kempe, M.D. Equating damp heat testing with field failures of PV modules. In Proceedings of the 39th IEEE Photovoltaic Specialists Conference (PVSC), Tampa, FL, USA, 16-21 June 2013; pp. $126-131$.

5. Osterwald, C.R.; McMahon, T.J. History of accelerated and qualification testing of terrestrial photovoltaic modules: a literature review. Prog. Photovolt. 2009, 17, 11-33. [CrossRef]

6. Wohlgemuth, J.H.; Kurtz, S. Using accelerated testing to predict module reliability. In Proceedings of the 37th IEEE Photovoltaic Specialists Conference, Seattle, WA, USA, 19-24 June 2011; pp. 3601-3605.

7. Wohlgemuth, J.H.; Cunningham, D.W.; Amin, D.; Shaner, J.; Xia, Z.; Miller, J. Using accelerated tests and field data to predict module reliability and lifetime. In Proceedings of the 23rd European Photovoltaic Solar Energy Conference and Exhibition (EUPVSEC), Valencia, Spain, 1-4 September 2008; pp. 2663-2669.

8. Bennett, I.J.; Roca, F.; Graditi, G.; Zubilaga, O.; Malbranche, P.; Zhu, J.; Gottschalg, R.; Köhl, M.; Hoffmann, S.; Berger, K.A.; et al. PV module lifetime prediction and quality assurance as addressed by SOPHIYA. In Proceedings of the 29th European Photovoltaic Solar Energy Conference and Exhibition (EUPVSEC), Amsterdam, The Netherlands, 22-26 September 2014; pp. 2495-2498.

9. Hacke, P.; Smith, R.; Terwilliger, K.; Glick, S.; Jordan, D.; Johnston, S.; Kempe, M.; Kurtz, S. Testing and analysis for lifetime prediction of crystalline silicon PV modules undergoing degradation by system voltage stress. IEEE J. Photvolt. 2013, 3, 246-253. [CrossRef]

10. Meyer, E.L.; van Dyk, E.E. Assessing the reliability and degradation of photovoltaic module performance parameters. IEEE Trans. Reliab. 2004, 53, 83-92. [CrossRef]

11. Khan, F.; Baek, S.H.; Kim, J.H. Intensity dependency of photovoltaic cell parameters under high illumination conditions: An analysis. Appl. Energy 2014, 133, 356-362. [CrossRef]

12. Khan, F.; Baek, S.H.; Park, Y.; Kim, J.H. Extraction of diode parameters of silicon solar cells under high illumination conditions. Energy Con. Manag. 2013, 76, 421-429. [CrossRef]

13. Phang, J.C.H.; Chan, D.S.H.; Phillips, J.R. Accurate analytical method for the extraction of solar cell model parameters. Electron. Lett. 1984, 20, 406-408. [CrossRef]

14. Khan, F.; Baek, S.H.; Kim, J.H. Wide range temperature dependence of analytical photovoltaic parameters for silicon solar cells under high illumination conditions. Appl. Energy 2016, 183, 715-724. [CrossRef]

15. Breitenstein, O.; Rakotoniaina, J.P.; Al Rifai, M.H.; Werner, M. Shunt type in crystalline silicon solar cells. Prog. Photovolt. 2004, 12, 529-538. [CrossRef]

16. Singh, S.N.; Kumar, D. Phenomenological model of anomalously high photovoltage generated in obliquely deposited semiconductor films. J. Appl. Phys. 2008, 103, 023713. [CrossRef]

17. Rummel, S.R.; McMahon, T.J. Effect of cell shunt resistance on module performance at reduced light levels. In Proceedings of the 13th NREL photovoltaics program review meeting, Lakewood, CO, USA, 16-19 May 1995; pp. 581-586.

18. Chakravarty, B.C.; Arora, N.K.; Singh, S.N.; Das, B.K. Solar cell performance with an inhomogeneous grain size distribution. IEEE Trans. Electron. Dev. 1986, 33, 158-160. [CrossRef]

19. Khan, F.; Singh, S.N.; Husain, M. Effect of illumination intensity on cell parameters of a silicon solar cell. Sol. Energy Mater. Sol. Cells 2010, 94, 1473-1476. [CrossRef] 
20. Khan, F.; Baek, S.H.; Kim, J.H. Determination of the diode parameters of a-Si and CdTe solar modules using variation of the intensity of illumination: An application. Sol. Energy 2011, 85, 2288-2294. [CrossRef]

21. Khan, F.; Baek, S.H.; Singh, S.N.; Singh, P.K.; Kim, J.H. Effective passivation of silicon surface by AZO films: application in bifacial solar cells. Sol. Energy 2013, 97, 474-483. [CrossRef]

22. Clifford, A.A. Multivariate Error Analysis: A Handbook of Error Propagation and Calculation in Many-Parameter Systems; John Wiley \& Sons: New York, NY, USA, 1973.

(c) (1)

(C) 2019 by the authors. Licensee MDPI, Basel, Switzerland. This article is an open access article distributed under the terms and conditions of the Creative Commons Attribution (CC BY) license (http://creativecommons.org/licenses/by/4.0/). 